\title{
PERSEPSI TERHADAP KONSUMSI KOPI DAN TEH MAHASISWA TPB-IPB TAHUN AJ ARAN 2007-2008
}

\author{
(Perception and Consumption of Coffee and Tea among Students at TPB-IPB \\ Period 2007/ 2008)
}

\author{
Febriana Ira Dewi ${ }^{1}$, Faisal Anwar ${ }^{1 *}$, dan Leily Amalia ${ }^{1}$ \\ ${ }_{1}^{1}$ Departemen Gizi Masyarakat, Fakultas Ekologi Manusia, Insitut Pertanian Bogor, Bogor 16680 \\ $1^{*}$ Alamat korespondensi: Departemen Gizi Masyarakat, Fakultas Ekologi Manusia, Institut Pertanian \\ Bogor, Bogor 16680. Telp: 0251-8621258; Fax: 0251-8622276; \\ Email: faisalanwar_gmipb@yahoo.com
}

\begin{abstract}
ABST RACT
Design of this research is a cross sectional study and study site in Bogor Agricultural Institute, Bogor. A total of 354 samples was drawn randomly. Average daily coffee and tea consumption were about $20.4 \mathrm{~g}$ and $1.93 \mathrm{~g}$. Coffee is usually consumed at night. Whereas, tea is consumed in the morning. Samples feel positive and negative effects after consumption of coffee and tea such us sleepless, fatigue, fresh, easy to concentrate, addiction, diuresis, and cardiac arrhythmias.
\end{abstract}

Keywords: coffee, tea, consumption.

\section{PENDAHULUAN}

Menurut data BPS (2007) perkembangan jumlah produksi kopi mengalami peningkatan 4.80\% yaitu 15583.48 ton pada tahun 2002 jadi 16331.45 ton pada tahun 2003. Jumlah produksi teh juga mengalami peningkatan pada tahun 2002 sampai 2003 yaitu 120421 ton jadi 127523 ton. Kopi dan teh memiliki kandungan kafein yang dikenal sebagai trimetilsantin (IFIC, 2007). Kafein umumnya dapat meningkatkan kewaspadaan, menurunkan perasaan lelah, meningkatkan suasana hati, dan kepercayaan diri. Meskipun demikian, kafein dapat memberikan dampak negatif bagi penggunanya seperti dapat memacu detak jantung, bersifat diuretik, dan meningkatkan tekanan darah (FKM UI, 2007).

Kafein merupakan salah satu stimulan yang paling luas penggunaannya, termasuk di kalangan remaja (Santrock 2003). Remaja cepat sekali terpengaruh oleh keadaan lingkungan terutama dalam pemilihan jenis makanan atau minuman. Kebiasaan konsumsi dapat membentuk suatu pola sikap yang dapat terjadi berulang-ulang dalam mengonsumsi pangan tertentu. Remaja cenderung mempunyai kebiasaan yang kurang baik yaitu lebih menyukai minuman ringan, teh, dan kopi dengan frekuensi lebih sering (Hurlock, 1996, dalam Puri, 2007). Konsumsi kafein khususnya kopi dan teh harus dibatasi yaitu tidak lebih dari $100 \mathrm{mg} /$ hari untuk menjaga kesehatan tubuh.
Berdasarkan hal tersebut, peneliti tertarik untuk meneliti pola konsumsi kopi-teh dan analisis dampaknya berdasarkan persepsi pada mahasiswa TPB-IPB tahun ajaran 2007/2008. Mahasiswa TPB-IPB tahun ajaran 2007/2008 dipilih sebagai calon responden karena merupakan representasi remaja yang berasal dari seluruh wilayah Indonesia.

Penelitian ini bertujuan untuk mengetahui pola konsumsi kopi-teh serta analisis dampaknya berdasarkan persepsi pada mahasiswa TPB-IPB tahun ajaran 2007/2008.

\section{METODE PENELITIAN}

\section{Desain, Tempat, dan Waktu Penelitian}

Desain penelitian ini dilakukan secara cross sectional study. Penelitian dilakukan di lingkungan kampus Institut Pertanian Bogor yaitu pada mahasiswa TPB-IPB tahun ajaran 2007/2008. Lokasi yang dipilih didasarkan pada pertimbangan bahwa belum terdapat penelitian mengenai pola konsumsi kopi-teh dan analisis dampaknya berdasarkan persepsi pada mahasiswa TPB-IPB serta kemudahan dalam pelaksanaan kegiatan penelitian karena lokasinya dapat dijangkau dengan mudah. Penelitian ini dilaksanakan pada bulan Februari 2008 - Juni 2008. 


\section{J umlah dan Cara Penarikan Contoh}

Populasi sampel dalam penelitian ini ialah mahasiswa putra dan putri TPB-IPB tahun ajaran 2007/2008. Jumlah populasi mahasiswa TPB-IPB tahun ajaran 2007/2008 sebanyak 3013 orang terdiri atas 1180 mahasiswa putra (39\%) dan 1833 mahasiswa putri (61\%).

Metode yang digunakan dalam penarikan sampel adalah pengambilan sampel acak sederhana (Simple Random Sampling) secara proporsional berdasarkan populasi mahasiswa putra maupun putri. Jumlah unit populasi dalam penelitian ini tidak sama dan responden yang diambil representatif berdasar jumlah populasi mahasiswa putra maupun putri. Kriteria responden penelitian ini adalah mengonsumsi kopi dan teh minimal satu kali dalam seminggu terakhir, bersedia mengisi kuesioner yang telah disiapkan peneliti dan mempunyai kesanggupan untuk diwawancarai. Jumlah responden diperoleh dengan menggunakan rumus Slovin. Rumus ini digunakan untuk menentukan jumlah minimal sampel yang dibutuhkan jika ukuran populasi diketahui. Rumus Slovin (Umar 2003) adalah sebagai berikut:

$$
\mathrm{n}=\frac{\mathrm{N}}{1+\mathrm{Ne}^{2}}
$$

Keterangan :

$$
\begin{aligned}
\mathrm{n}= & \text { ukuran sampel } \\
\mathrm{N}= & \text { ukuran populasi } \\
\mathrm{e}= & \text { kesalahan pengambilan sampel yang dapat } \\
& \text { ditolerir }(5 \%)
\end{aligned}
$$

Formula yang digunakan dalam menentukan proporsi responden tiap kelompok yaitu

$$
\mathrm{n}=\frac{\mathrm{Ni}}{\mathrm{N}} \mathrm{n}
$$

Keterangan: $I=1$. Putra

\section{Putri}

Berdasarkan rumus Slovin, jumlah responden yang diperlukan dalam penelitian ini sebanyak 354 orang. Persentase mahasiswa putra maupun putri dalam populasi terdiri dari 61\% mahasiswa putri dan 39\% mahasiswa putra sehingga diperoleh jumlah responden putra maupun putri masing-masing sebanyak 138 dan 216 orang.

\section{Pengolahan dan Analisis Data}

Data yang diperoleh diolah menggunakan Microsoft Excel for Windows 2003 dan dilanjutkan dengan menggunakan Statistical Package for Social Sciences (SPSS) 13.0 for Windows. Tahapan pengolahan data meliputi verifikasi, coding, entry, editing, dan analisis. Uji beda dilakukan untuk melihat adanya perbedaan karakteristik individu antara responden putra dan putri, perbedaan jumlah dan frekuensi konsumsi kopi dan teh pada responden putra dan putri. Hubungan karakterisitik individu dengan pola konsumsi (jumlah dan frekuensi) kopi-teh serta hubungan jumlah konsumsi kopi dan teh dengan dampak positif dan negatif yang dirasakan dianalisis menggunakan uji korelasi Spearman. Uji beda yang digunakan yaitu uji u (Mann Whitney).

\section{HASIL DAN PEMBAHASAN}

\section{Karakteristik Individu}

Umur

Sebagian besar responden putra $(67.4 \%)$ responden putri (74.1\%) berusia antara 17-18 tahun. Responden putra dan putri yang berusia 19-20 tahun masing-masing sebesar $32.6 \%$ dan $25.9 \%$. Berdasarkan hasil uji beda, tidak terdapat perbedaan yang nyata umur responden putra dan putri $(\mathrm{P}>0.05)$.

Tabel 1. Sebaran Responden berdasarkan Umur

\begin{tabular}{lcccccc}
\hline \multirow{2}{*}{ Umur (tahun) } & \multicolumn{2}{c}{ Putra } & \multicolumn{2}{c}{ Putri } & \multicolumn{2}{c}{ Total } \\
\cline { 2 - 7 } & $\mathbf{n}$ & $\%$ & $\mathbf{n}$ & $\%$ & $\mathbf{n}$ & $\%$ \\
\hline $17-18$ & 93 & 67.4 & 160 & 74.1 & 253 & 71.5 \\
$19-20$ & 45 & 32.6 & 56 & 25.9 & 101 & 28.5 \\
Total & 138 & 100.0 & 216 & 100.0 & 354 & 100.0 \\
Rata-rata \pm std & \multicolumn{2}{c}{$18.3 \pm 0.6$} & $18.2 \pm 0.6$ & \multicolumn{2}{c}{$18.2 \pm 0.6$} \\
\hline
\end{tabular}

Keterangan: $p$-value: 0.214

\section{Uang Saku}

Besar uang saku yang diterima responden tiap bulan merupakan akumulasi dari pemberian orang tua, beasiswa atau sumber lainnya yang digunakan untuk memenuhi kebutuhan hidup sehari-hari selama tinggal di asrama. Berdasarkan hasil penelitian, sebagian besar responden putra $(80.4 \%)$ maupun putri $(76.0 \%)$ memiliki besar uang saku antara Rp 362000 sampai 704000 . Uang saku yang diterima responden putra dan putri setiap bulannya tidak termasuk untuk membayar SPP dan sewa kamar di asrama. Berdasarkan hasil uji beda, tidak terdapat perbedaan yang nyata besar uang saku per bulan antara responden putra dan putri $(p>0.05)$.

\section{Pengetahuan Tentang Kafein}

Sebagian besar responden putra (74.6\%) dan sebagian besar responden putri (78.7\%) memiliki pengetahuan tentang kafein pada kategori sedang. Sedangkan responden putra dan putri yang memiliki pengetahuan tentang kafe- 
in pada kategori baik masing-masing sebesar $18.1 \%$ dan $12.5 \%$. Pengetahuan tentang kafein yang baik tidak sepenuhnya diikuti dengan praktek konsumsi yang baik dalam kehidupan sehari-hari.

Berdasarkan hasil uji beda, terdapat perbedaan pengetahuan tentang kafein antara responden putra dan putri $(p<0.01)$. Tabel 3 menunjukkan kecenderungan skor rata-rata pengetahuan tentang kafein responden putri lebih tinggi dibanding responden putra. Hal ini menunjukkan bahwa responden putri memiliki informasi lebih luas mengenai pengetahuan tentang kafein dibandingkan responden putra. Secara umum responden putri lebih banyak yang mengerti dibandingkan responden putra yang dilihat dari kemampuan dalam menjawab setiap jenis pertanyaan yang diajukan.

\section{Keragaan Konsumsi Kopi-teh}

Persentase responden putra dan putri yang mengonsumsi maupun tidak mengonsumsi kopi dan teh dapat dilihat secara rinci pada Tabel 4. Berdasarkan hasil uji beda, tidak terdapat perbedaan jumlah responden putra dan putri yang biasa mengonsumsi kopi dan teh $(p>0.05)$. Hal ini menunjukkan bahwa mahasiswa putra dan putri yang mengonsumsi dan tidak mengonsumsi kopi-teh sama banyaknya.

Tabel 5 menunjukkan kandungan kafein pada beberapa produk pangan yang digunakan untuk mengestimasi kandungan kafein yang dikonsumsi responden pada tiap produk pangan (kopi, teh). Kopi murni mempunyai kandungan kafein lebiuh tinggi bila dibandingkan dengan kopi instan. Teh hijau mempunyai kandungan kafein lebih tinggi bila dibandingkan dengan kandungan kafein teh hitam.

Tabel 2. Sebaran Responden berdasarkan Besar Uang Saku

\begin{tabular}{lcccccc}
\hline \multirow{2}{*}{ Besar Uang Saku (Rp/bln) } & \multicolumn{2}{c}{ Putra } & \multicolumn{2}{c}{ Putri } & \multicolumn{2}{c}{ Total } \\
\cline { 2 - 7 } & $\mathbf{n}$ & $\%$ & $\mathbf{n}$ & $\%$ & $\mathbf{n}$ & $\%$ \\
\hline$<$ Rp 362 000.00 & 15 & 10.9 & 23 & 10.6 & 38 & 10.7 \\
Rp 362 000.00-704 000.00 & 111 & 80.4 & 164 & 76.0 & 275 & 77.7 \\
Rp 704 000.00 & 12 & 8.7 & 29 & 13.4 & 41 & 11.6 \\
Total & 138 & 100.0 & 216 & 100.0 & 354 & 100.0 \\
$\quad$ Rata-rata \pm sd & $521.775 \pm 156.620$ & $540.277 \pm 179.528$ & & $533.065 \pm 170.974$ \\
$\quad$ (Rp.1 000.00) & \multicolumn{7}{c}{} & &
\end{tabular}

Keterangan: $p$-value: 0.155

Tabel 3. Sebaran Responden berdasarkan Pengetahuan Tentang Kafein

\begin{tabular}{|c|c|c|c|c|c|c|c|}
\hline \multirow{2}{*}{$\begin{array}{c}\text { Kategori Pengetahuan tentang } \\
\text { Kafein }\end{array}$} & \multicolumn{2}{|c|}{ Putra } & \multicolumn{2}{|c|}{ Putri } & \multicolumn{3}{|c|}{ Total } \\
\hline & $n$ & $\%$ & $\mathbf{n}$ & $\%$ & $\mathbf{n}$ & $\%$ & \\
\hline Kurang & 10 & 7.3 & 19 & 8.8 & 29 & & 8.2 \\
\hline Sedang & 103 & 74.6 & 170 & 78.7 & 273 & & 77.1 \\
\hline Baik & 25 & 18.1 & 27 & 12.5 & 52 & & 14.7 \\
\hline Total & 138 & 100.0 & 216 & 100.0 & 354 & & 100.0 \\
\hline Skor Rata-Rata \pm sd & \multicolumn{2}{|c|}{$70.2 \pm 8.8$} & \multicolumn{2}{|c|}{$73.0 \pm 10.8$} & \multicolumn{3}{|c|}{$71.9 \pm 10.2$} \\
\hline
\end{tabular}

Keterangan: p-value: 0.009

Pengetahuan tentang kafein (kurang $<60 \%$, sedang $60-80 \%$ dan baik $>80 \%$ )

Tabel 4. Sebaran Responden berdasarkan Konsumsi Pangan Sumber Kafein

\begin{tabular}{|c|c|c|c|c|c|c|c|c|c|}
\hline \multirow{3}{*}{$\begin{array}{l}\text { Pangan } \\
\text { Sumber } \\
\text { Kafein }\end{array}$} & \multicolumn{4}{|c|}{ Putra } & \multicolumn{4}{|c|}{ Putri } & \multirow{3}{*}{ p-value } \\
\hline & \multicolumn{2}{|c|}{ Mengonsumsi } & \multicolumn{2}{|c|}{ Tidak } & \multicolumn{2}{|c|}{ Mengonsumsi } & \multicolumn{2}{|c|}{ Tidak } & \\
\hline & $\mathrm{n}$ & $\%$ & $\mathbf{n}$ & $\%$ & $\mathbf{n}$ & $\%$ & $\mathbf{n}$ & $\%$ & \\
\hline Kopi & 67 & 48.5 & 71 & 51.5 & 89 & 41.2 & 127 & 58.8 & 0.175 \\
\hline Teh & 105 & 76.1 & 33 & 23.9 & 156 & 72.2 & 60 & 27.8 & 0.421 \\
\hline
\end{tabular}

Tabel 5. Kandungan Kafein pada Kopi dan Teh

\begin{tabular}{cc}
\hline \multicolumn{1}{c}{ Minuman } & Kandungan Kafein (mg) dalam 200 $\mathbf{~ m l}$ \\
\hline${ }^{a}$ Kopi : Kopi murni & 71.8 \\
Kopi instant & 63.4 \\
${ }^{\text {b}}$ Teh: Teh hitam & 52.5 \\
Teh hijau & 58.9 \\
\hline
\end{tabular}

Sumber: ${ }^{a}$ IFIC ( International Food Information Council Foundation) 2007

${ }^{\mathrm{b}}$ Hicks (1996), diacu dalam Soraya (2008) 


\section{J enis Kopi-teh yang Dikonsumsi}

Sebagian besar responden putra (85.1\%) dan responden putri (91.0\%) mengonsumsi jenis kopi instant. Hal ini diduga rasanya lebih disukai dan tidak mempunyai ampas serta kopi instant dapat dikombinasikan dengan susu, krim, gula atau tambahan flavor lain. Menurut Sitorus (2007) umumnya kalangan pelajar dan mahasiswa hanya sedikit yang menyukai jenis kopi murni karena tidak tahan dengan rasa pahit kopi dan mempunyai ampas.

Menurut SNI (2002) kopi instant merupakan produk kering yang mudah larut dalam air, diperoleh seluruhnya dengan cara mengekstrak biji tanaman kopi yang telah disangrai. Kopi instant juga dibuat dengan komposisi kopi, gula, krim, susu atau dengan penambahan flavor sehingga memberi rasa yang enak. Hanya sebesar $14.9 \%$ responden putra dan $9.0 \%$ responden putri yang mengonsumsi jenis kopi murni. Kopi murni umumnya disukai oleh golongan orang tua karena aroma dan rasanya masih asli dibandingkan kopi instant. Berdasarkan hasil uji beda, tidak terdapat perbedaan jenis kopi yang dikonsumsi pada responden putra dan putri $(p>0.05)$.

Berdasarkan hasil penelitian, didapatkan bahwa sebagian besar responden putra maupun responden putri mengonsumsi jenis teh hitam masing-masing sebesar $86.7 \%$ dan $89.1 \%$. Menurut Khomsan (2005), sebagian besar (98\%) teh yang beredar dipasaran yaitu teh hitam. Berdasarkan hasil uji beda, tidak terdapat perbedaan jenis teh yang dikonsumsi pada responden putra dan putri $(p>0.05)$.

\section{Pola Konsumsi Pangan Sumber Kafein \\ Frekuensi dan jumlah konsumsi kopi}

Frekuensi konsumsi kopi merupakan salah satu cara untuk mengetahui pola konsumsi kopi dan memberikan gambaran berapa kali responden mengonsumsinya dalam satu minggu. Berdasarkan hasil penelitian, sebagian besar responden putra $(70.1 \%)$ dan sebagian besar responden putri $(86.5 \%)$ umumnya jarang mengonsumsi kopi (1-3 kali/minggu) (Tabel 7). Berdasarkan hasil uji beda, terdapat perbedaan yang nyata frekuensi konsumsi kopi pada responden putra maupun putri $(p<0.01)$. Ratarata frekuensi konsumsi kopi pada responden putra nilainya relatif lebih besar $(3.6 \pm 3.0 \mathrm{kali}$ /minggu) dibandingkan responden putri (2.4 \pm $1.7 \mathrm{kali} / \mathrm{minggu})$. Rata-rata frekuensi konsumsi kopi pada kedua kelompok responden tersebut yaitu $2.9 \pm 2.4 \mathrm{kali} / \mathrm{minggu}$.

Sebagian besar responden putra (88.1\%) dan sebagian besar responden putri $(97.8 \%)$ mengonsumsi kopi sebanyak kurang dari 20.4 gram per hari (Tabel 8). Semakin banyak jumlah kopi yang dikonsumsi maka akan berpengaruh pula terhadap jumlah kafein yang masuk dalam tubuh. Berdasarkan hasil uji beda, terdapat perbedaan yang nyata jumlah konsumsi kopi pada responden putra maupun putri $(p<0.01)$. Jumlah konsumsi kopi pada responden putra jumlahnya $(11.9 \pm 10.9$ gram per hari) relatif lebih besar dibandingkan dengan responden putri $(7.4 \pm 5.6$ gram per hari).

Menurut IFIC (2007) kandungan kafein dalam kopi murni dan kopi instant masingmasing $71.8 \mathrm{mg}$ dan $63.4 \mathrm{mg}$ dalam $200 \mathrm{ml}$ se-

Tabel 6. Sebaran Responden berdasarkan Jenis/Bentuk Pangan Sumber Kafein yang Dikonsumsi

\begin{tabular}{|c|c|c|c|c|c|c|c|c|}
\hline \multirow{2}{*}{$\begin{array}{c}\text { Pangan Sumber } \\
\text { Kafein }\end{array}$} & \multirow{2}{*}{ J enis/Bentuk } & \multicolumn{2}{|c|}{ Putra } & \multicolumn{2}{|c|}{ Putri } & \multicolumn{2}{|c|}{ Total } & \multirow{2}{*}{ p-value } \\
\hline & & $\mathbf{n}$ & $\%$ & $\mathbf{n}$ & $\%$ & $\mathbf{n}$ & $\%$ & \\
\hline \multirow[t]{2}{*}{ Kopi } & Kopi instan & 57 & 85.1 & 81 & 91.0 & 138 & 88.5 & \\
\hline & Kopi murni/tubruk & 10 & 14.9 & 8 & 9.0 & 18 & 11.5 & 0.252 \\
\hline Total & & 67 & 100.0 & 89 & 100.0 & 156 & 100.0 & \\
\hline \multirow[t]{2}{*}{ Teh } & Teh hitam & 97 & 92,4 & 146 & 93,6 & 243 & 93.1 & \\
\hline & Teh hijau & 8 & 7.6 & 10 & 6.4 & 18 & 6.9 & 0.548 \\
\hline Total & & 105 & 100.0 & 156 & 100.0 & 261 & 100.0 & \\
\hline
\end{tabular}

Tabel 7. Sebaran Responden berdasarkan Frekuensi Konsumsi Kopi

\begin{tabular}{lrrrrrr}
\hline \multirow{2}{*}{ Frekuensi Konsumsi (kali/minggu) } & \multicolumn{2}{c}{ Putra } & \multicolumn{2}{c}{ Putri } & \multicolumn{2}{c}{ Total } \\
\cline { 2 - 7 } & \multicolumn{1}{c}{$\mathbf{n}$} & \multicolumn{1}{c}{$\%$} & $\mathbf{n}$ & \multicolumn{1}{c}{$\%$} & $\mathbf{n}$ & \\
\hline Jarang (1-3) & 47 & 70.1 & 77 & 86.5 & 124 & 79.5 \\
Cukup sering (4-6) & 6 & 9.0 & 3 & 3.4 & 9 & 5.8 \\
Sering ( $\geq 7$ ) & 14 & 20.9 & 9 & 10.1 & 23 & 14.7 \\
Total & 67 & 100.0 & 89 & 100.0 & 156 & 100.0 \\
Rata-rata \pm sd & \multicolumn{2}{c}{$3.6 \pm 3.0$} & $2.4 \pm 1.7$ & & $2.9 \pm 2.4$ \\
\hline
\end{tabular}

Keterangan: $p$-value: 0.005 
duhan kopi. Berdasarkan hal tersebut maka diperoleh estimasi jumlah kafein pada kopi yang dikonsumsi responden yaitu $21.5 \pm 19.8 \mathrm{mg}$ per hari dengan rata-rata jumlah konsumsi kopi $9.3 \pm 8.6$ gram per hari $(60.0 \mathrm{ml}$ seduhan kopi). Batasan konsumsi kafein kopi kira-kira 300 mg per hari (kira-kira 3 cangkir kopi per hari) tidak menyebabkan gangguan kesehatan pada kalangan dewasa.

\section{Frekuensi dan Jumlah Konsumsi Teh}

Sebagian besar responden putra (65.7\%) dan sebagian besar responden putri (64.7\%) mengonsumsi teh dengan frekuensi jarang yaitu 1-3 kali per minggu (Tabel 9). Sedangkan rata-rata frekuensi konsumsi teh pada responden adalah 4.0 $\pm 3.2 \mathrm{kali} /$ minggu. Berdasarkan hasil uji beda, tidak terdapat perbedaan nyata frekuensi konsumsi teh pada responden putra maupun putri $(p>0.05)$. Menurut Khomsan (2005) teh mengandung kafein (4\% dari berat kering) yang dapat memberikan efek stimulan bagi tubuh. Efek stimulan tersebut akan menyebabkan seseorang merasa lebih segar sehingga dapat menunjang aktivitas.

Menurut Hodgson et al. (2003) $250 \mathrm{ml}$ seduhan teh dibuat dari dua gram teh bubuk. Lebih dari separuh jumlah responden putra (65.7\%) maupun responden putri (66.7\%) me- ngonsumsi teh kurang dari 1.93 gram per hari (Tabel 10). Estimasi jumlah kafein pada teh yang dikonsumsi responden yaitu $39.3 \pm 33.8 \mathrm{mg}$ per hari dengan rata-rata konsumsi teh yaitu $1.2 \pm 1.0$ gram per hari (150 $\mathrm{ml}$ seduhan teh).

Semakin banyak jumlah konsumsi teh maka dapat menjadi suatu kebiasaan namun tidak menimbulkan bahaya seperti ketagihan obat apabila dikonsumsi dalam jumlah wajar (Wiseman 2002). Berdasarkan hasil uji beda, tidak terdapat perbedaan jumlah konsumsi teh pada responden putra maupun putri $(p>0.05)$.

\section{Kondisi dan Waktu Konsumsi Pangan Sumber Kafein}

Tabel 11 menunjukkan bahwa lebih dari separuh jumlah responden (70.5\%) mengonsumsi kopi pada saat mengerjakan tugas/begadang/ujian. Bagi pelajar umumnya minum kopi pada saat banyak tugas biasanya memang sudah menjadi kebiasaannya karena dapat mencegah timbulnya rasa kantuk. Pengaruh sugesti responden mengakibatkan adanya anggapan bahwa minum kopi lebih tepat dikonsumsi untuk mengurangi kantuk saat mengerjakan tugas. Konsumsi kopi pada responden bertujuan agar tubuh mereka tetap terjaga dari kantuk saat kondisi tertentu.

Tabel 8. Sebaran Responden berdasarkan Jumlah Konsumsi Kopi

\begin{tabular}{lrrrrrr}
\hline \multirow{2}{*}{ Kategori Konsumsi (g/hari) } & \multicolumn{2}{c}{ Putra } & \multicolumn{2}{c}{ Putri } & \multicolumn{3}{c}{ Total } \\
\cline { 2 - 8 } & \multicolumn{1}{c}{ n } & \multicolumn{1}{c}{ n } & \multicolumn{1}{c}{$\%$} & \multicolumn{1}{c}{ \% } & \multicolumn{1}{c}{$\%$} \\
\hline Rendah $(<20.4)$ & 59 & 88.1 & 87 & 97.8 & 146 & \\
Sedang (20.4-40.8) & 7 & 10.4 & 2 & 2.2 & 9 & 5.6 \\
Tinggi (>40.8) & 1 & 1.5 & 0 & 0.0 & 1 & 0.6 \\
Total & 67 & 100.0 & 89 & 100.0 & 156 & 100.0 \\
Rata-rata \pm sd & $11.9 \pm 10.9$ & $7.4 \pm 5.6$ & \multicolumn{2}{c}{$9.3 \pm 8.6$} \\
\hline
\end{tabular}

Keterangan: $\mathrm{p}$-value: 0.001

Tabel 9. Sebaran Responden berdasarkan Frekuensi Konsumsi Teh

\begin{tabular}{|c|c|c|c|c|c|c|}
\hline \multirow{2}{*}{ Frekuensi Konsumsi (kali/minggu) } & \multicolumn{2}{|c|}{ Putra } & \multicolumn{2}{|c|}{ Putri } & \multicolumn{2}{|c|}{ Total } \\
\hline & $\mathbf{n}$ & $\%$ & $\mathbf{n}$ & $\%$ & $\mathbf{n}$ & $\%$ \\
\hline Jarang (1-3) & 69 & 65.7 & 101 & 64.7 & 170 & 65.1 \\
\hline Cukup sering (4-6) & 0 & 0.0 & 0 & 0.0 & 0 & 0.0 \\
\hline Sering $(\geq 7)$ & 36 & 34.3 & 55 & 35.3 & 91 & 34.9 \\
\hline Total & 105 & 100.0 & 156 & 100.0 & 261 & 100.0 \\
\hline Rata-rata $\pm s d$ & \multicolumn{2}{|c|}{$4.0 \pm 3.0$} & \multicolumn{2}{|c|}{$4.0 \pm 3.4$} & \multicolumn{2}{|c|}{$4.0 \pm 3.2$} \\
\hline
\end{tabular}

Keterangan: p-value: 0.323

Tabel 10. Sebaran Responden berdasarkan Jumlah Konsumsi Teh

\begin{tabular}{|c|c|c|c|c|c|c|}
\hline \multirow{2}{*}{ Kategori Konsumsi (g/hari) } & \multicolumn{2}{|c|}{ Putra } & \multicolumn{2}{|c|}{ Putri } & \multicolumn{2}{|c|}{ Total } \\
\hline & $\mathbf{n}$ & $\%$ & $\mathbf{n}$ & $\%$ & $n$ & $\%$ \\
\hline Rendah $(<1.93)$ & 69 & 65.7 & 104 & 66.7 & 173 & 66.3 \\
\hline Sedang (1.93-3.86) & 34 & 32.4 & 49 & 31.4 & 83 & 31.8 \\
\hline Tinggi $(>3.86)$ & 2 & 1.9 & 3 & 1.9 & 5 & 1.9 \\
\hline Total & 105 & 100.0 & 156 & 100.0 & 261 & 100.0 \\
\hline Rata-rata $\pm s d$ & \multicolumn{2}{|c|}{$1.2 \pm 0.9$} & \multicolumn{2}{|c|}{$1.2 \pm 1.0$} & \multicolumn{2}{|c|}{$1.2 \pm 1.0$} \\
\hline
\end{tabular}

Keterangan: p-value: 0.325 
Sebagian besar responden (83.5\%) mengonsumsi teh dalam kondisi santai (Tabel 11). Minum teh terasa nikmat bila dikonsumsi saat kondisi santai karena dapat memberi kesegaran bagi tubuh. Hanya sebesar $8.4 \%$ responden yang mengonsumsi teh saat kondisi lelah, dingin, stres dan saat akan kuliah.

Tabel 11. Sebaran Responden berdasarkan Kondisi Konsumsi Kopi dan Teh

\begin{tabular}{lrrrr}
\hline \multirow{2}{*}{ Kondisi } & \multicolumn{2}{c}{ Kopi } & \multicolumn{2}{c}{ Teh } \\
\cline { 2 - 5 } & \multicolumn{1}{c}{$\mathbf{n}$} & \multicolumn{1}{c}{$\%$} & \multicolumn{1}{c}{$\mathbf{n}$} & \multicolumn{1}{c}{$\%$} \\
\hline Santai & 66 & 42.3 & 218 & 83.5 \\
Olahraga & 0 & 0.0 & 36 & 13.8 \\
Mengerjakan tugas & 110 & 70.5 & 74 & 28.4 \\
(belajar), begadang,ujian & 21 & 13.5 & 47 & 18.0 \\
Bepergian & 4 & 2.6 & 22 & 8.4 \\
Lainnya &
\end{tabular}

Keterangan: Ada responden yang mengonsumsi pangan sumber kafein lebih dari satu kondisi

Tabel 12 menunjukkan bahwa sebagian besar responden $(80.1 \%)$ terbiasa mengonsumsi kopi pada malam hari. Menurut Khomsan (2005) minum kopi di malam hari dapat membantu mengalahkan rasa kantuk sehingga tugas dan pekerjaan bisa diselesaikan dengan lancar.

Lebih dari separuh jumlah responden (55.6\%) mengonsumsi teh saat pagi hari (Tabel 12). Menurut Yahya (1992) umumnya teh dikonsumsi sebagai minuman pagi maupun sore hari. Sebagian kecil responden $(20.0 \%)$ mengonsumsi teh di waktu siang hari mungkin di sela-sela jam makan siang.

Tabel 12. Sebaran Responden berdasarkan Waktu Konsumsi Kopi dan Teh

\begin{tabular}{|c|c|c|c|c|}
\hline \multirow{2}{*}{ Waktu } & \multicolumn{2}{|c|}{ Kopi } & \multicolumn{2}{|c|}{ Teh } \\
\hline & $n$ & $\%$ & $n$ & $\%$ \\
\hline Pagi & 34 & 21.8 & 145 & 55.6 \\
\hline Siang & 16 & 10.3 & 52 & 20.0 \\
\hline Sore & 13 & 8.3 & 63 & 24.1 \\
\hline Malam & 125 & 80.1 & 84 & 32.2 \\
\hline
\end{tabular}

\section{Dampak Konsumsi Kopi dan Teh}

\section{Dampak positif}

Tabel 13 menunjukkan bahwa hampir seluruh responden $(92.3 \%)$ merasa rasa kantuknya berkurang setelah minum kopi. Dampak tersebut dapat dirasakan karena responden tidak cepat mengantuk setelah mengonsumsi kopi dibandingkan dengan kondisi biasa. Menurut Khomsan (2005), minum kopi dapat membuat tubuh seseorang menjadi terjaga sehingga dapat memacu aktivitasnya. Sebagian besar responden menyatakan bahwa setelah minum kopi, mereka bisa begadang tanpa merasakan kantuk.
Kopi lebih dikenal sebagai minuman untuk mencegah rasa kantuk. Hal tersebut dapat terbukti pada seseorang yang sensitif terhadap keberadaan kafein dalam kopi. Kandungan kafein dalam kopi lebih tinggi dibandingkan dengan teh, sehingga responden lebih memilih minum kopi sebagai minuman penghilang rasa kantuk. Menurut Liebermen (2001), dalam IFIC (2007), tubuh menjadi lebih terjaga dari tidur dan berenergi setelah mengonsumsi 75-150 mg kafein.

Tabel 13 menunjukkan bahwa lebih dari separuh jumlah responden (52.1\%) menyatakan bahwa setelah minum teh merasa kelelahan menjadi berkurang. Adanya pengaruh kafein dalam teh membantu mengurangi rasa lelah yang dirasakan. Sebesar 38.3\% jumlah responden mempunyai anggapan merasa lebih tenang setelah mengonsumsi teh. Menurut Sihadi (2007) kafein mampu memperbaiki emosi saat sedang gelisah sehingga menjadi lebih tenang. Selain pengaruh kafein, kandungan gula dalam minuman teh juga dapat dimanfaatkan tubuh untuk menambah tenaga. Tingkat kesensitifan yang berbeda terhadap kafein dapat memberikan pengaruh yang berbeda pada tiap individu. Sebagai informasi tambahan, berdasarkan data penelitian terakhir diketahui bahwa kopi mengandung polifenol lebih tinggi daripada teh dan coklat. Hal ini menunjukkan bahwa kopi juga berpeluang untuk berfungsi sebagai pangan sumber antioksidan

\section{Dampak Negatif}

Persentase terbesar responden (42.9\%) merasa ketagihan setelah mengonsumsi kopi artinya ada keinginan kembali untuk mengonsumsi kopi (Tabel 14). Hal ini diduga dipengaruhi oleh nikmatnya rasa kopi yang khas. Kopi instan merupakan jenis kopi yang biasa dikonsumsi responden karena rasanya yang enak sehingga memiliki citarasa yang lebih disukai responden dibandingkan dengan kopi murni.

Persentase terbesar responden (33.3\%) menyatakan bahwa setelah konsumsi teh frekuensi buang air kecil menjadi semakin sering dibandingkan jika tidak mengonsumsi teh (Tabel 14). Menurut Miller (1960) efek fisiologis kafein dalam teh dapat mempercepat pengeluaran urin. Kafein dapat merangsang ginjal untuk membentuk dan membuang air seni lebih banyak dari jumlah air yang diminum.

\section{Hubungan Karakteristik Responden dengan Konsumsi Kopi-Teh}

Hasil uji statistik menunjukkan tidak terdapat hubungan antara umur dan uang saku 
responden dengan frekuensi konsumsi kopi dan teh. Hal ini diduga karena umur mahasiswa dan uang saku yang diperoleh setiap bulannya relatif sama.

Hasil uji statistik menunjukkan tidak terdapat hubungan pengetahuan gizi dan kafein dengan frekuensi konsumsi teh. Namun, terdapat kecenderungan bahwa semakin tinggi pengetahuan gizi dan kafein, maka frekuensi konsumsi kopi pada responden semakin jarang $(p<0.1, r=-0.138)$.

\section{Konsumsi Kopi-Teh dengan Dampak yang Dirasakan}

Semakin tinggi jumlah konsumsi kopi, responden menyatakan bahwa rasa lelah semakin berkurang $(p<0.05 r=0.168)$, merasa mudah berkonsentrasi $(p<0.01 r=0.221)$ dan jadi lebih tenang $(p<0.01 r=0.292)$. Hasil uji statistik menunjukkan terdapat hubungan antara jumlah konsumsi kopi dengan dampak negatif yang dirasakan berupa ketagihan $(p<0.05$ $r=0.201$ ). Semakin tinggi jumlah konsumsi kopi, maka responden semakin merasa ketagihan. Namun, konsumsi kopi dalam jumlah rendah dan rutin ternyata dapat pula menyebabkan ketagihan bagi responden untuk mengonsumsinya kembali. Hasil penelitian juga menunjukkan terdapat kecenderungan hubungan jumlah konsumsi kopi dengan keseringan buang air kecil. Semakin tinggi jumlah konsumsi kopi, maka terdapat kecenderungan responden semakin sering buang air kecil $(p<0.1, r=0.155)$.

Menurut Sugiyono \& Muchtadi (1989) kafein dalam kopi berfungsi sebagai perangsang yang bersifat bukan alkohol. Kebiasaan responden mengonsumsi kopi juga mengakibatkan tubuh lebih toleran terhadap keberadaan kafein dalam tubuh. Menurut Wiseman (2002) sensitifitas seseorang terhadap kafein dapat berbeda-beda sehingga terdapat kemungkinan kopi tidak menimbulkan pengaruh apapun meskipun mengandung $60 \mathrm{mg}$ kafein.

Semakin tinggi jumlah konsumsi teh, maka terdapat kecenderungan responden semakin merasa lelahnya berkurang $(p<0.1, r=$ 0.144). Menurut Santrock (2003) kafein dalam pangan dapat menurunkan perasaan lelah. Hasil uji statistik menunjukkan tidak terdapat hubungan antara jumlah konsumsi teh dengan dampak positif yang dirasakan berupa rasa kantuk berkurang, lebih bugar, mudah konsentrasi dan merasa lebih tenang $(p>0.05)$. Selain itu juga tidak terdapat hubungan jumlah konsumsi teh dengan dampak negatif yang dirasakan $(p>0.05)$.

\section{KESIMPULAN}

Responden putra $(67.4 \%)$ maupun putri (74.1\%) umumnya berusia 17-18 tahun dengan uang saku rata-rata Rp 533 065. Responden putra (74.6\%) maupun putri (78.7\%) umumnya memiliki pengetahuan gizi dan kafein pada kategori sedang.

Frekuensi konsumsi kopi dan teh pada mahasiswa putra dan putri termasuk kategori jarang (1-3 kali/minggu) dengan masing-masing jumlah konsumsi yaitu <20.4 gram dan

Tabel 13. Sebaran Responden berdasarkan Dampak Positif Konsumsi Kopi dan Teh

\begin{tabular}{lrrrr}
\hline \multirow{2}{*}{ Dampak Positif } & \multicolumn{2}{c}{ Kopi } & \multicolumn{2}{c}{ Teh } \\
\cline { 2 - 5 } & \multicolumn{1}{c}{$\mathbf{n}$} & \multicolumn{1}{c}{ n } & $\%$ \\
\hline Rasa kantuk berkurang & 144 & 92.3 & 39 & 14.9 \\
Lebih bugar & 38 & 24.4 & 70 & 26.8 \\
Lelah berkurang & 25 & 16.0 & 136 & 52.1 \\
Mudah konsentrasi & 32 & 20.5 & 90 & 34.5 \\
Merasa lebih tenang & 35 & 22.4 & 100 & 38.3 \\
Lainnya & 0 & 0.0 & $2^{*}$ & 0.8 \\
\hline
\end{tabular}

Tabel 14. Sebaran Responden berdasarkan Dampak Negatif Konsumsi Kopi dan Teh

\begin{tabular}{lrrrr}
\hline \multicolumn{1}{c}{ Dampak Negatif } & \multicolumn{2}{c}{ Kopi } & \multicolumn{2}{c}{ Teh } \\
\cline { 2 - 5 } & $\mathbf{n}$ & \multicolumn{1}{c}{ \% } & n & \multicolumn{1}{c}{$\%$} \\
\hline Sakit kepala & 46 & 29.5 & 15 & 5.7 \\
Merasa jantung berdetak lebih cepat & 58 & 37.2 & 13 & 5.0 \\
Ketagihan & 67 & 42.9 & 49 & 18.8 \\
Sering buang air kecil & 29 & 18.6 & 87 & 33.3 \\
Gangguan maag & 35 & 22.4 & 9 & 3.4 \\
Mudah lapar setelah makan & 28 & 17.9 & 35 & 13.4 \\
Lainnya & $1^{*}$ & 0.6 & 0 & 0.0 \\
\hline
\end{tabular}


$<1.93$ gram. Terdapat perbedaan dalam frekuensi dan jumlah konsumsi kopi $(p<0.01)$ antara responden putra dan putri. Tidak terdapat perbedaan dalam hal frekuensi dan jumlah konsumsi teh.

Dampak positif yang paling banyak dirasakan responden setelah mengonsumsi kopi dan teh yaitu rasa kantuk berkurang pada kopi (92.3\%) dan lelah berkurang pada teh (52.1\%). Sedangkan dampak negatif yang paling banyak dirasakan responden setelah mengonsumsi kopi dan teh yaitu merasa ketagihan pada kopi $(42.9 \%)$ dan sering buang air kecil pada teh (33.3\%).

Terdapat hubungan yang signifikan antara pengetahuan gizi dan kafein dengan konsumsi kopi yaitu semakin tinggi pengetahuan gizi dan kafein, maka jumlah dan frekuensi konsumsi kopi semakin rendah.

\section{DAFTAR PUSTAKA}

[BPS] Biro Pusat Statistik. 2007. Pertanian. http://www.bps.go.id. [8 Agustus 2008]

- 2007. Estates Production by Crops Indonesia, 1995-2006 (Ton). http:// www.bps.go.id. [7 November 2007].

FKM UI. Fakultas Kesehatan Masyarakat Universitas Indonesia. 2007. Gizi dan Kesehatan Masyarakat. PT Raja Grafindo Persada, Jakarta.

Hodgson, Burke V, Beilin LJ, Croft KD, \& Puddey IB. 2003. Black tea influence plasma total homocystein concentrations. J Clin Nutr 77, 908-911.

IFIC International Food Information Council Foundation. 2007. Caffeine and Health: Clarifyng The Controversies. http:// www.ific.org. [30 Desember 2007].

Khomsan A. 2005. Pangan dan Gizi untuk Kesehatan. Edisi kedua. Rajagrafindo Persa- da, Jakarta
Miller S. 1960. Introduction to Foods and Nutrition. John Wiley \& Sons, Inc, New York.

Muchtadi D \& Sugiyono. 1989. Ilmu Pengetahuan Bahan Pangan. Bogor: Departemen Pendidikan dan Kebudayaan Dirjen Pendidikan Tinggi Pusat Antar Universitas Pangan dan Gizi, IPB, Bogor.

Puri D. 2007. Faktor-faktor yang berhubungan dengan status anemia mahasiswi peserta program pemberian makan tambahan di IPB, Bogor. Skripsi Sarjana Fakultas Pertanian, IPB, Bogor.

Santrock J. 2003. Perkembangan Remaja edisi ke 6. (Adelar dan Saragih, penerjemah). Erlangga, Jakarta.

Sitorus L. 2007. Analisis Faktor-Faktor yang Mempengaruhi Kepuasan Konsumen terhadap Kopi Instant Kemasan Sachet di Wilayah Jakarta Timur. Skripsi Sarjana Fakultas Pertanian, IPB, Bogor.

SNI. 2002. Produk Kopi, Teh, Coklat. Bogor: Pusat Antar Universitas Pangan dan Gizi, IPB, Bogor.

Soraya N. 2008. Isolasi Kafein dari Limbah Teh Hitam CTC Jenis Powdery Secara Ekstraksi. Skripsi Sarjana Fakultas Teknologi Pertanian, IPB, Bogor.

Umar H. 2003. Metode Riset Perilaku Konsumen Jasa. Ghalia Indonesia, Jakarta.

Wiseman G. 2002. Nutrition and Health. Departemen of Biomedical Science University of Sheffield UK, London. Taylor and Francis, New York.

Yahya VJ . 2002. Kadar kafein dan beberapa jenis produk kopi dan teh serta sifat biologinya (Studi Kasus di Daerah Bogor). Media Gizi dan Keluarga. 16 (2), 26-34. 